\title{
Maciej Kierzkowski
}

maciej.kierzkowski@open.ac.uk

The Open University

England

\section{Brass Band Contests in Poland as an Expression of Socio-musical Movement}

\author{
Konkursy orkiestr dętych w Polsce jako ekspresja \\ ruchu społeczno-muzycznego
}

\begin{abstract}
Summary: This paper deals with the issue of brass bands' contests in Poland and is analysed using both the diachronic and systematic approaches. The sources for this inquiry are the international literature relating to the working class contest phenomena and the outcome of my ethnomusicological field research conducted in 2001-2005 in the Mazovia region (Central Poland). I briefly examine the history of contests of brass bands in Poland since the interwar period. The systematic part deals with different aspects of contesting, which include motivations of musicians, organisers' assumptions, performed repertoire, as well as evaluation criteria. I explore the structure of brass band contest and its roles in bands' development. The national, multileveled format of musical contest, is described in relation to the fireman band movement, which was being animated by the Main Board of Voluntary Fire Brigades - a non-musical organisation, and corresponds with the well-researched phenomenon of brass band movement in Great Britain.
\end{abstract}

Key words: brass band, contest, Poland, music, culture, ethnomusicology, Mazovia

Streszczenie: Artykuł dotyczy konkursów orkiestr dętych w Polsce i stanowi analizę z wykorzystaniem metod diachronicznych i systematycznych. Źródłem dla tego badania jest międzynarodowa literatura poświęcona zjawiskom związanych z konkursami orkiestr dętych oraz wyniki moich badań terenowych w dziedzinie etnomuzykologii przeprowadzonych w latach 2001-2005 na Mazowszu (Polska Centralna). Krótko omawiam historię konkursów orkiestr dętych w Polsce od okresu międzywojennego. Część systematyzująca dotyczy różnych aspektów konkursu, w tym motywacji muzyków, założeń organizatorów, wykonywanego repertuaru, a także kryteriów oceny. Opisuję strukturę konkursu i jego rolę w rozwoju zespołów. Ogólnokrajowy, wielopoziomowy format konkursu muzycznego zaprezentowany jest w odniesieniu do ruchu strażackich orkiestr dętych, który jest animowany przez Zarząd Główny Ochotniczych Straży Pożarnych - organizację niemuzyczną, i odpowiada w pewnym stopniu dobrze zbadanemu ruchowi orkiestr dętych w Wielkiej Brytanii.

Słowa klucze: orkiestra dęta, konkurs, Polska, muzyka, kultura, etnomuzykologia, Mazowsze

Tłumaczenie: Klaudyna Michałowicz 


\section{Introduction}

This paper outlines the phenomena of brass band contests in Poland, including their psycho-social and aesthetic conditions. I will briefly examine both the historical reports on brass band contests in Poland and the international literature concerning brass band contests in other countries. The methodology applied to this study includes library inquires, ethnomusicological field research as well as comparative analysis in regard to the systematics, changes and international context of the phenomena of brass bands in Mazovia (Central Poland). The main primary sources for this study include transcribed interviews, audio-visual recordings, occasional prints and iconography. One of the aims of this paper is to explore the structure of brass bands contests in Poland, the criteria of adjudicators, performing conventions and repertoire. The other goal is to explore the role of the contests in the development of brass bands in Poland which can be considered in three different contexts: institutional, social and individual. Through these investigations this paper will contribute to English literature on brass bands, which does not refer to brass band contests in Poland.

\section{Literature review}

The literature concerning the issue of brass band contests in Poland can be divided into publications in two different languages with two different approaches. One approach focuses on the broader international context, while the other presents the local Polish one. The work of English-speaking authors considers different European traditions of brass bands, often referring to the contests and their roles and functions in the development of bands. Polish writers, for which brass bands are rarely the key area of study, provide some information about the contests in an incidental manner. Any discussions of the brass band contests in Poland are purely descriptive: a detailed analysis of their roles is not provided. Furthermore these two bodies of literature (Polish and other international) generally do not refer to each other, even though some of these studies are published in the same volumes.

The socio-musical roles of brass band contests are analysed in the international research written in English, but the literature deals rather with cases that exist outside Poland. Globally, it is considered that "in many band traditions today the very motivation for band participation centres on competitions" (Brucher, Reily 2013: 27). Contests are perceived to have been at the centre of the British brass movement, which since the middle of the nineteenth century has been crucial for the establishment of the British model of the brass band (British brass band) (Herbert 2000). In Finland, already in the 1880s competitions of brass septets were organised along with music composition contests 
during national music festivals (Karjalainen 1995). The amateur brass band contests, which are widespread in France, have their origins in the tradition of the Orphéon musical movement (Dubois, Méon, Pierru 2016). Since 1961 both brass bands and individual trumpeters have competed during a festival in Guča in Serbia, which is regarded as the biggest trumpet festival in the world and an important venue for the preservation of local traditional music (Tadič 2014).

There is relatively little literature concerning the roles of brass band contests in Poland and existing published work is actually part of studies dealing with wider subjects, such as amateur music-making or social history. One key contribution to the literature is by Szaflik (2001), whose work has focused on the history of the Voluntary Fire Brigades (VFB) - a nationwide association for voluntary fireman activity in Poland. It appears that the first brass band competitions in Poland were organised in the interwar period (1918-1939) for the bands affiliated with the fireman societies, and the reported aim of these contests was to improve the skills of fireman brass bands (Szaflik 2001). Studies that mention the development of brass band contests in Poland after World War II include several masters theses by students of the High School of Music in Warsaw (Hejman 1974; Marchwicka 1976; Ważyński 1982; Węgiel 1966). Contests were organised to increase the "qualifications" of brass bands, and for "widening the scope of their work" (Węgiel 1966: 28). Bands in factories and work places had opportunities to take part in the competitions organised by workers' unions (Marchwicka 1976) as well as during brass band festivals (Ważyński 1982). Separate contests and inspections were organised for railway brass bands (Hejman 1974).

\section{Methodology and Sources}

Besides the above investigation of existing relevant literature, the main methodologies applied to this study have been ethnomusicological field research (Nettl 1964) followed by the comparative analysis of the phenomena of brass bands in the Mazovia region of Poland. The field work included methods of psychology (interviews), anthropology (observation of musical situations from an outsider position), sociology (questionnaire surveys) and ethnomusicology (audio-visual recordings of interviews and musical performances), all accompanied by photographic documentation. The majority of source material was collected during research conducted in 2001-2005 in the Mazovia region of Central Poland. This collection of primary material comprised 28 interviews with individuals from the brass band world in Poland (bandsmen, conductors, members of institutions supporting 
the brass band movement, contest judges) ${ }^{1}$, audio and video recordings of bands' performances and rehearsals, unpublished (often handwritten) material and iconography (e.g. photographs from private collections). Regarding the issue of contests, especially interesting sources include the occasional publications of brass band festivals (advertisements, flyers, booklets) and concert programmes, as well as printed judges' forms and other official documents disseminated by the contest organisers.

\section{The Ethnography of Brass Band Contests in Mazovia}

The sources described above provide important information about the role of brass band contests in Poland, and the structure of the phenomenon and its role in the development of the bands. An examination of structure of these musical competitions entails consideration of the evaluation criteria of adjudicators, the variability of performing conventions and the different functions of the bands' repertoire. The analysis presented below demonstrates that the role of the contests in the development of brass bands in Poland functioned on three different levels that concern institutional, social and individual aspects of banding.

The research conducted in the Mazovia region in Poland has highlighted brass band contests as a special occasion for artistic performance, in which bands of the same (mostly fireman) institutional affiliation compete. The musical performances during contests are mostly departure events, which take place outside the home districts of bands. During contests, brass bands perform music on the move (during the drilling parade) or in static convention, which is usually short concert of typically three musical pieces of a spectacular character. Additionally there are special live acts with more than one brass band playing together, which are artistic performances of repertoire nominated previously by all participating bands. Constraints on participation in the contest apply to both the musical repertoire that is presented and the appearance (costumes) of the musicians who perform there. ${ }^{2}$

The contests are a stable element of the nationwide inspections of fireman brass bands that are organised by the Voluntary Fire Brigades on the different territorial and administrative levels in a biannual cycle. There are local, regional and nationwide brass band contests, while the finals take place each time in different localisations - usually in the main cities of Poland. The local inspections are usually organised in regions of one or two counties, in relation to the number of bands existing in the region. The prize winners are

\footnotetext{
${ }^{1}$ The transcriptions of the interviews are added as an appendix to my master thesis concerning brass bands of Mazovia (Kierzkowski, 2005).

${ }^{2}$ For example during the nation-wide inspections of fireman brass bands each participating band has to perform at least one piece by Polish composer and to wear unitary fireman outfits.
} 
promoted to higher level events, where they compete with the winners of contests organised in different areas. The inspections are co-organised by the local boards of the VFB as well as by communal governments and cultural institutions.

The repertoire performed during brass band competitions in Poland can be divided into three main groups, and the classification takes into account the performance conventions. Contest repertoires of brass bands in Poland include: 1) concert repertoires, 2) marches, 3) musical pieces performed by joint brass bands. The performances of the first two groups are judged by the jury. The concert repertoire is usually presented in static convention, on a stage, and in a spectacular manner. It comprises musical pieces of both an artistic or entertaining nature. Most concert performances are of instrumental music - less of vocal-instrumental (e.g. adaptations of current popular hit-songs) - and potpourris, marches and dance songs predominate. The artistic repertoire consists mainly of arrangements of musical works by prominent European composers of classical music (e.g. Fryderyk Chopin, Johannes Brahms, George Frideric Handel). They are seen as ambitious works to perform and are prepared by bands especially for contest presentations. During the competitions this repertoire is usually performed in a cycle of three pieces. The marching repertoire is played during the drilling parade and usually consists of musical pieces by Polish, Czech, Russian, German and American composers. The repertoire performed during the concerts of joint bands are usually popular fireman marches (e.g. Hymn Strażacki, Na straży), and most often the adaptation of the popular Polish hit-song about brass bands: Orkiestry dęte sung by Halina Kunicka.

The repertoire presented during brass band contests in Poland is mostly arranged and adapted by the bandmasters for the needs of their own bands. The instrumental configuration of brass bands in Poland, which are "variable and varied" and depend in most cases on local conditions (the availability of instruments, the number of people willing to play, individual preferences of musicians and bandmasters, current fashions, bandsmen's ages), correspond with the generally small number of original compositions for brass band in the concert repertoire (Kierzkowski 2005). The situation in Poland is very different to models in other European countries. In Britain, thanks to the standardisation of the instrumental configuration of brass bands in the 20th century, during contests it became possible to perform standard brass band arrangements (test-pieces) and original compositions for a uniform brass band format (Herbert 2000). In Finland, one of the most important forms of repertoire for Finnish brass septets are the potpourris - pieces composed and arranged for the particular requirements of national music festivals, which are also often obligatory during contests (Karjalainen 1995). 
Most artistic performances during brass band contests in Poland are evaluated by professional juries, according to specific criteria. The adjudication boards consists typically of experts ("people from the world of culture"), such as conductors of Polish military bands $^{3}$, representatives of governmental cultural institutions, public record companies publishing recordings of brass bands (e.g. the Polskie Nagrania record label), as well as members of organisations associated with brass bands and supporting their activities (e.g. The Polish Association of Choirs and Orchestras; the VFB). The assessment criteria include both musical and visual facets, and correspond with categories of excellence of musical performance formulated by interviewed conductors. The professional evaluation of artistic performances include such factors as the technical and musical level of the band, its orchestral skills, the art of performance, sound quality, choice of repertoire, general artistic expression and style of performance. ${ }^{4}$ Additionally, the quality of the instrumental arrangement of the pieces presented as well as visual elements of performance (e.g. order, formation, uniforms, female dancers' participation, etc.) are also subjects of assessment.

The role of brass band contests in the development of bands in Poland can be analysed on different levels that include institutional, social and individual aspects. The institutional level deals with the general support for bands, increasing their artistic skill and social impact, what is manifested in statements published in official documents disseminated among brass bands by the organisers of contests. For example, the aims stated in a document issued in 1999 during the Sixteenth Nationwide VFB Brass Band Inspection, included such objectives as: the presentation of the artistic achievement of bands; propagation of music in society; the focus of cultural leaders and local branches of the VFB on the impact of the "correctly developing fireman band movement" on culture; the constant increase in the artistic standards of the VFB musical bands "throughout the elements of friendly rivalry". Hence, it is possible to distinguish two general categories of the motivations of the contests' organisers upon an institutional level: 1) educational and utilitarian goals concerning dissemination and propagation of music; 2) aims referring to the promotion and artistic development of particular bands. One noteworthy aspect of this process is the use in official contest documents of the term "fireman band movement", which corresponds with the phenomenon of the brass band movement in Great Britain, which is frequently discussed in scholarship published in English (Herbert 2000).

\footnotetext{
${ }^{3}$ E.g. conductors of the Representative Band of Polish Army.

${ }^{4}$ The evaluation card of the Third Inter-county Inspection of VFB Brass Bands Orkiestriada 2002 in Różan consisted of following musical elements: intonation, rhythmic, dynamics, articulation, tempo, phrasing, accentuation, form, interpretation.
} 
The social roles of brass band contests in Poland mainly concerns the organisation and management of bands' activities in regard to the musical rivalry. Taking part in a brass band competition constitutes often a significant challenge for a brass band, and usually demands additional financial investment; it is also the source of many benefits, though not necessarily material ones. The costs of attending contests usually include such issues as: the transport of the band, accommodation and food during the departure performances, purchases of uniforms, and sometimes the participation of professional musicians who are hired occasionally to fill any gaps in instrumental line-ups. Contests assume also additional obligations for bands, such as: greater commitment to rehearsals, the preparation of new repertoire and the practice of unusual performance conventions (e.g. the drilling parade). The benefits gained from participation in the contests include the development of a band's prestige and strengthening band identity.

An important feature of the contests, which is applicable on both social and individual levels, is the meaning of success. Triumphs in competitions are usually cherished by brass bands and are announced in bands' chronicles. Trophies and diplomas are usually kept in the bands' archives in visible points. Prizes that are won in contests are often an additional motivation, especially for conductors ${ }^{5}$, to raise the level of the band's performance abilities, as well as being a kind of symbolic remuneration for the time spent in creating arrangements and composing. A prize in the competition is not only of great value to the conductor and the bandsmen - being the confirmation of great musical skill - but also influences reception of the band, increasing a band's popularity in the local community. Thanks to these competitions, brass bands have become a showcase of their localities in the supra-local arena - regional, national and international. They are the source of pride and an important element of local patriotism. The material benefits of participating in competitions consist not only of the valuable prizes received, like costly musical instruments, but also offers of paid concerts, grants, bonuses for the purchase of uniforms and cash prizes. Any financial rewards are in general provided to the band's treasurer and are usually allocated to common team needs, such as the sewing of new uniforms and the purchase and maintenance of musical instruments. Sharing of earned money between musicians is a rare practice.

The impact of brass band contests on an individual level concerns the motivations of particular bandsmen and conductors. Interviewees mentioned several factors that encourage participation in contests: the opportunity to confront, compete and compare

\footnotetext{
5 "The most important [for me] was the participation in the nationwide competition of brass bands in Koszalin in 1979, where we won the prize of the president of Koszalin. That was equal to the third place in the country at all. It was our success" (interview with Tadeusz Miętus - former conductor of the Trąbki Brass Band, 2001.08.29.).
} 
with other bands; the will to "be better"; the ability to obtain professional jury ratings; the opportunity to watch other conductors; and the possibility of better integration with the band. For younger musicians, trips to competitions act as rewards for additional work carried out in preparation for performances as well as reinforcing identification with the band. One recent development concerns changes to the motivations of musicians as a result of the impact of electronic media on customs in Poland in the second half of the 20th century. Interviewees reported a decrease in interest in brass band competitions in the 1970s, especially among musicians who played in other (e.g. wedding) bands. During this period many musicians ceased to show willing to participate in competitions and were absent from rehearsals due to "gigs" played with other bands. In such situations, many conductors began to hire (for money) professional musicians to fill the gaps in their own instrumental configurations during contest performances.

\section{Conclusion}

In this paper I have explored different properties of brass band contests in Poland, drawing on existing literature and my own empirical research on the Mazovia region. It is clear that the development of brass bands in Poland is being affected by the contest process on different levels, in institutional, social and individual aspects. It seems that amateur civilian brass band competitions in Poland are largely related to the activity of the Voluntary Fire Brigades, which have defined the fireman band movement since the interwar period to the present day. The goals of the contests' organizers coincide closely with the motives of the individual conductors and the bandsmen themselves. The organization of the competitions and participation in them are motivated more by nonmaterial aims than by financial benefits, while the role of these competitions has both a musical dimension that influences the increase in the band's musical skill, and social one that enables integration and identification with a band. It is worth emphasizing that in Mazovia (and in Poland more widely) the main institution that had encouraged the fireman brass band movement, manifested in multileveled contest formulae, is the Voluntary Fire Brigades - a non-musical institution, whose main purpose is the prevention of fires. This model of sociocultural development deserves detailed scholarly attention as does the analysis of material collected in the archives of institutions involved in the

\footnotetext{
6 "This is a factor that definitely creates and stimulates the band's activity. This is the release of the will to be better. This is the only way the bands have the chance to raise their level at all" (interview with Jerzy Łubian - former conductor of the Youth Brass Band of Pilawa, 2003.03.01.).

${ }^{7}$ The popularity of brass band competitions of other types of institutional affiliation (e.g. brass bands with the industrial patronage) refers to the era of the Polish People's Republic (1945-1989), when these bands enjoyed state patronage and were treated in a privileged way by the state.
} 
local brass band movement (e.g. the Main Board of VFB). Investigations of these collections would make an important contribution to existing scholarship on the history of the brass bands in Poland.

\section{Bibliography}

Brucher, K., Reily, S. A. (2013). Introduction. In: S. A. Reily, K. Brucher (eds.), Brass Bands of the World: Militarism, Colonial Legacies, and Local Music Making (p. 1-32). New York: Routledge.

Dubois, V., Méon, J.-M., Pierru, E. (2016). The Sociology of Wind Bands. Amateur Music Between Cultural Domination and Autonomy. New York: Routledge.

Hejman, K. (1974). Działalność muzyczna klubów Związku Zawodowego Kolejarzy (praca magisterska). Państwowa Wyższa Szkoła Muzyczna w Warszawie.

Herbert, T. (2000). Introduction. In: T. Herbert (ed.), The British Brass Band. A Musical and Social History (p. 1-9). Oxford: OUP Oxford.

Karjalainen, K. (1995). Suomalainen Torviseitsikko. Historia ja perinteen jatkuminen. Tampere. Tampereen yliopisto.

Kierzkowski, M. (2005). Orkiestry dęte Mazowsza. Uwarunkowania historyczno-ekonomiczne, psychospołeczne i estetyczne (praca magisterska). Uniwersytet Warszawski.

Marchwicka, E. (1976). Robotnicze zespoły muzyczne w Warszawie (praca magisterska), Państwowa Wyższa Szkoła Muzyczna w Warszawie.

Nettl, B. (1964). Theory and Method in Ethnomusicology. New York: Free Press.

Szaflik, J. R. (2001). Dzieje Ochotniczych Straży Pożarnych. Warszawa: Ludowa Spółdzielnia Wydawnicza.

Tadič, A. (2014). Brass Bands in Serbia. Zwierciadło etnologiczne. Rocznik Katedry Etnologii i Antropologii Kulturowej Uniwersytetu Szczecińskiego, 3, 121-126.

Ważyński, R. (1982). Orkiestra Dęta RZPS Radoskór i jej wpływ na kulturę muzyczną środowiska (praca magisterska). Akademia Muzyczna im. Fryderyka Chopina w Warszawie.

Węgiel, F. (1966). Organizowanie i prowadzenie amatorskich orkiestr dętych (praca magisterska). Państwowa Wyższa Szkoła Muzyczna w Warszawie. 
